\title{
Robert Benne
}

Roanoke College, Salem, Virginia, USA

(D) https://orcid.org/0000-0002-1710-9665

\section{God's Holy Ordinance}

It is not your love that sustains the marriage, but From now on, the marriage that sustains your love.

Dietrich Bonhoeffer,

Wedding Sermon (Letters and Papers From Prison) ${ }^{1}$

\begin{abstract}
In this article, I argue that the church must build up its theology of marriage in a more disciplined manner because the culture no longer sustains the Christian notion. In making a substantive argument I rely on the Lutheran "two ways that God reigns" approach in which we share "places of responsibility" with all humans, but in which the Christian virtues of faith, love, and hope transform those places into genuine Christian callings. I then contend strongly for the continued rejection of same-sex marriage among orthodox Christians. I conclude with what I hope is a compassionate pastoral approach—gracious tolerance-toward homosexual Christians.
\end{abstract}

Keywords: individualism, places of responsibility, faith, love, hope, gracious tolerance

\section{Our Situation}

"What is assumed is not understood," said a wise but anonymous person. That wise saying is certainly applicable to the ethic of sex and marriage. For so long a particular Judeo-Christian version of that ethic was embedded in our culture that few paused to understand and defend it. Even the churches did little to understand it; they, too, floated on the momentum of the culture.

\footnotetext{
${ }^{1}$ Dietrich Bonfhoeffer, Letters and Papers from Prison (London: S.C.M. Press, 1953), 150.
} 
I can remember no one-neither parent, nor church, nor school-instructing me about the immorality of premarital sex, about the indissolubility of the marriage bond, abut sexual fidelity in marriage, about the joyful obligation to have children, and the heterosexual nature of the bond. But I knew what was right, as did my compatriots growing up in the 1950s. Everything in the culture reinforced the ideal, including the popular entertainment of the day. (Ingrid Bergmann had to flee Hollywood when it became known that she had a child out of wedlock.) I astound my students when I tell them that in my growing up years I knew no one whose parents were divorced.

I am not so naïve to think that that ideal was followed scrupulously by everyone. There certainly were those who went astray. My wife and I were attendants in at least one "hurried" matrimony. But the ideal was strong enough that it was not difficult to find a prospective mate who held to those ideals, which we did when we found each other.

The culture has come a long way since then, mostly downward with regards to a wholesome ethic of sex and marriage. One of the most helpful analyses of this culture was offered some time ago, and then updated, by Robert Bellah in his Habits of the Heart. ${ }^{2}$ In that book he argued that the two great normative visions of life that made up America - what he calls Republican and Biblical virtue - have been subverted by two new forms of radical individualism, the utilitarian and the expressive. The older visions of life bore and were transmitted by practices - including marriage - that enfolded intrinsic goods into their performance. These visions with their attendant practices were carried by communities shaped by formative narratives. The newer individualisms have no narratives that gather them into communities of vision and are corrosive of strong connections among persons and communities.

Utilitarian individualism - aiming at personal success through disciplined self-interest - tends to view marriage as a limited contract between two wary, self-interested parties. (The prenuptial agreement is vividly illustrative of this utilitarian view.) Expressive individualism - devoted to the free expression of internal states-views marriage as desirable only as long as individuals can express and satisfy their needs within a tentative agreement to be together. When the bells no longer ring, it is time to move on. ${ }^{3}$

Since both forms of individualism view institutions with suspicion, since they involve persisting commitments outside the self, they are also wary of marriage. Thus, we get an exponential growth in cohabitation, in which public commitment is not required. Cohabitation is the fitting fruit of both kinds of individualism.

${ }^{2}$ Robert Bellah et al., Habits of the Heart: Individualism and Commitment in American Life (Berkeley, CA: University of California Press, 1985, 1996), 27ff.

${ }^{3}$ Bellah, Habits of the Heart, 142ff. 
We have also witnessed an exponential growth in sex outside of marriage. Everybody's doing it, says the popular media in every possible way. A Martian visiting the earth from afar might guess that sex only happens outside marriage. In our popular culture, sex has been detached from commitment; it has also been detached from procreation. And, increasingly, it is being detached from bodily form. Sex has been plunged into what Freud called "polymorphous perversity."

We are now aware of the terrible toll that this transformation in sexual behavior has wrought in broken marriages and families, troubled children, venereal diseases, and chaotic personal behavior. No doubt some good has come from this transformation, but on the whole, the effects seem to me to be perverse.

Meanwhile, the church has not taken seriously this powerful cultural shift. The last two generations have been powerfully influenced by the unfolding individualism I spoke of above. They are likely to hold unstable mixtures of Christian and cultural notions of sex and marriage. The church continues to meander along when a dramatic battle is going on for the soul of its young. This complacence is evident in the lack of Christian education programs-including both religious and moral elements - being mounted by our churches. We need much more serious educational formation of our young. A sign of that need is the emergence of home-schooling in our country by serious Christian families. Christian parents have lost trust in both public education and the church when it comes to their children's ethical formation.

At any rate, we now have a world in which the Christian ethic of sex and marriage is neither assumed nor understood. It is time to rebuild our understanding of the Christian marriage and sexual ethic since we can no longer assume one. The following is meant to offer a Christian theological and moral vision of marriage, and by implication, a Christian view of proper sexual norms of behavior. It will discuss homosexual behavior in that larger context.

\section{Marriage as a Place of Responsibility}

To this day in Germany, one goes to the magistrate for a civil marriage and to the church for a Christian marriage. This duality indicates that Lutherans believe the institution of marriage has a civic status, independent of the church's blessing of same. This is because Lutherans inalterably argue that God has not left the world bereft of his creating, governing and judging presence after the Fall. God has preserved certain forms - called "Orders of Creation"- to order and sustain the human community. In the Old Testament this "First Institution," 
in Luther's words, was founded before the fall. ${ }^{4}$ "Therefore a man leaves his father and mother and cleaves to his wife, and they become one flesh. And the man and his wife were both naked, and were not ashamed" (Gen. 2:24).

This "place of responsibility" is something that is shared by the whole world, whether Christian or not. As an estate of God, it is oriented toward preserving and sustaining the creation. It is a dike to sin, it provides for permanent loving unions, it is the place for bearing and nurturing children, and it is a platform for service to the world. Many religions and cultures endorse these basic ends of marriage, though they may define marriage in different ways. Even in our dissembling culture, those ends are still held in high esteem, yet ensconced in law and custom. In all societies it is a crucial institution. That is why there is widespread alarm in almost all the countries of Europe and North America, where marriage is less practiced and less stable than earlier.

The orders of creation and the obligations that go with them-Lutheran version of the natural law - have been thought to be accessible to human reason and experience. But they-like Catholic versions of natural law-are best viewed in the light of the revelation of God in the Old Testament, where God reveals his will for our life together. He wills a covenantal existence for us in the varied places where we live our responsible lives out, marriage being the primal covenant that God offers man and woman in their mutual needs and possibilities. That covenantal existence is ordered by the Law of God, which sometimes operates incognito in the consciences and experiences of people and at other times explicitly through the Commandments of God. The Law of God contends in human existence with human propensities toward sin, so that every concrete historical manifestation of covenantal existence is marred by sin. Even so, all cultures at their best reflect the tug of God's Law by shaping bonds between men and women that are faithful, fruitful, and permanent.

It seems that marriage in the Old Testament gradually moves from polygamy toward monogamy, so that by the time of the New Testament, the latter provides the normative model. ${ }^{5}$ That certainly seems to be the moral norm taught by Jesus and Paul. But though there were a variety of models of marriage in Old Testament Judaism, as well as in other world religions, there is overwhelming unanimity that the structure of marriage is heterosexual, again as in all other world religions.

The unanimity on heterosexual marriage is matched by the unanimity of opposition to homosexual relations in general. There is an overwhelming consensus that there is a divinely created structure to sexual life. ${ }^{6}$ Women and men are meant to complement each other in sex and marriage. They "fit" together

${ }^{4}$ Martin Luther, American Edition of Luther's Works, ed. Jaroslav Pelikan and Helmut Lehmann, (Philadelphia: Fortress Press; St. Louis: Concordia Publishing House, 1955-1986), 1: 103.

${ }^{5}$ See John Witte, Jr., From Sacrament to Contract: Marriage, Religion, and Law in the Western Tradition, 2nd edition (Louisville: John Knox Press, 2012), $43 \mathrm{ff}$.

${ }^{6}$ Witte, From Sacrament to Contract, 15. 
physically, emotionally, and spiritually. They have the possibility of procreation. Some of this "fit" is of course culturally constructed, but that construction is built on solid biological, even ontological, grounds. Male and female God created them, and they are meant to be together in the bonds of marriage. This is a near universal in human historical and cultural experience. And it is crystal clear in the Hebrew and Christian Scriptures; one does not need proof texts to demonstrate the heterosexual nature of marriage and sexual relations in the Bible. Indeed, that fact is even conceded by the proponents of homosexual unions, only they call the phenomenon "heterosexism."

If what I said is true in Section I, our ideals about and practice of marriage are in disarray, not only in society but also in church. The general agreements suggested in Section II have diminished in normative power. We have weak assumptions and even weaker understandings. The corrosive individualism that disturbs society also affects the people of the church. So it behooves us to come to a better understanding of and training for marriage in the Christian community.

\section{Marriage as a Christian Calling}

Building on the theological notion that God wills the ordinance of marriage in all the world, we will now move on to a particularly Christian understanding of marriage.

We are now moving from marriage as an ordinance or estate to marriage as a holy ordinance or a holy estate. Or, we are moving from marriage as a place of responsibility to marriage as a Christian calling.

The church brings three great Christian virtues to bear on the ordinance of marriage to make it a holy ordinance-faith, love, and hope. Likewise, wellformed Christians bring those virtues with them as they transform a place of responsibility into a calling.

Faith is first of all faith in the justifying grace of God in Christ that affirms and forgives those who believe in the Gospel promises of God. That grace is radical and universal, offered to all who cast themselves upon the mercy of God in Christ, whether they are married or unmarried, young or old, rich or poor. This is the "vertical" dimension of faith. But for the Christian who receives the Gospel through the power of the Spirit, the same Spirit makes faith practically effective in the world. This is the "horizontal" dimension of faith, if you will. 


\section{A. Faith}

1. Its first effect is to discern the deeper level of meaning and reality that inheres in the institution of marriage. Marriage is discerned as an estate founded and willed by God. His will undergirds the deep purposes of marriage-faithful union, procreation, and service to the world. Marriage is not simply an emergent of cultural evolution, a purely human construction, or the product of necessary repression for the sake of an orderly civilization. Rather, "The Lord God in his goodness created us male and female, and by the gift of marriage founded human community [...]." " Jesus quotes Genesis 2:24 as to the divine origin of marriage when he debates the nature of marriage vows with the Pharisees (Mk 10:7-8). Luther affirms that the "lawful joining together of a man and a woman is a divine ordinance and institution." ${ }^{9}$ Bonhoeffer certainly delineates the divine, objective character of Christian marriage when he writes to a young couple about to be married:

Your love is your own private possession, but marriage is more than something personal - it is a status, an office [...]. As high as God is above man, so high are the sanctity, the rights, and the promise of marriage above the sanctity, the rights, and the promise of love. It is not your love that sustains the marriage, but from now on, the marriage sustains your love. ${ }^{10}$

The sacred canopy that is marriage hallows our life together, shielding us from the confusion and disorder of the world. It provides the protected space under which marital love can grow. When we live in accordance with God's establishment, we move with God's will; when we ignore it or violate it, we rebel against something more than human convention. Lord help the church that rebels against God's establishment by violating or distorting it.

2. The second practical work of faith is to enable persons entering marriage to see their roles as a calling from God. They come to see themselves playing a role in the covenantal existence that God has provided for them. They enter Christian marriage in a disciplined fashion, responding to God's call to be formed into the Christian vision of marriage.

This Christian vision can be discussed briefly under two rubrics - the context and time frame of the marriage vow. First, let us look at the context. Far from being limited to a private vow between two persons, as our individualistic

7 This exposition of the virtues can be found more fully in my book, Ordinary Saints: An Introduction to the Christian Life (Minneapolis: Fortress Press, 1988, 2003), chap. six.

${ }^{8}$ Lutheran Book of Worship (Philadelphia: Board of Publication, Lutheran Church in America, 1978), 203.

${ }^{9}$ Luther, American Edition of Luther's Works, 1: 134.

${ }^{10}$ Bonhoeffer, Letters and Papers from Prison, 150. 
culture seems to maintain, Christian promise-keeping has many contexts, all of which are publicly important. Like the public and historical nature of God's vow to Israel and Jesus's vow to the church, Christian marriage vows are historical and public.

There is of course the interpersonal nature of the vow: "I take you to be my wife/husband from this day forward [...]." But that is preceded by an intrapersonal vow: I promise myself that I take the other in faithfulness. I agree to bind myself to that vow. From there the context broadens. Promises are made before family and friends, who witness its solemnity and vow to support the couple in their life together. Further, the vow is made in the context of the church-the pastor symbolizing that context. Vows are made to conform to this universal community's particular understanding of marriage. That understanding has been blessed by Jesus "who gladdened the wedding at Cana in Galilee."11 The vows are also made in the legal context of the state, which has an interest in sound and stable marriage. But, finally and most importantly, the vows are made before God, who has ordained this estate and called the participants to play their roles in the institution he has founded.

These ever-widening contexts bestow a powerful social quality on Christian marriage. It renders pale and insufficient current practices of "living together," which lack the objectivity and seriousness of public vows. Christian promises reverberate far beyond the couple alone. They establish the couple within an ongoing community that finally claims divine sanction for its practice.

The time frame of Christian marriage is as long as the context is wide. The marriage that Christians are called to was created from the beginning by the Lord God, "who created our first parents and established them in marriage."12 That foundation extends continuously throughout history through many generations to the present day.

By vowing to enter this tradition in the present, a Christian couple makes a sharp break with their earlier life by entering into this new covenant. Their vows indicate a powerful rite of passage. After this moment, loyalties are rearranged, financial responsibilities change, a new home is founded, and the "two become one." This moment of transition opens the way for sexual relations; properly so, for it marks the moment of public commitment and validation. It is fitting that the access to the most intimate and life-promising of exchanges be given at that time. Just as priests do not baptize or marry, judges do not render decisions, and presidents do not issue presidential orders until vows are made and validated, so new privileges - as well as responsibilities - come with the vows.

\footnotetext{
${ }^{11}$ Lutheran Book of Worship, 201.

${ }^{12}$ Lutheran Book of Worship, 203.
} 
Christian marriage has a future dimension as well. There are solemn intentions toward a permanent bond. "I promise to be faithful to you until death parts us." We are to "find delight in each other and grow in holy love until life's end."'13 At the moment of marriage, the partners themselves as well as their mutualities are immature. The vows of permanence are assurances that the partners will give each other and their relationship the time to grow and flourish. They recognize with Jesus that what God who puts together no one should put asunder.

\section{B. Love}

The crown of Christian marriage is its affirmation of agape love, a special kind of reflected love that is characterized by unconditionedness, steadfastness, otherregarding faithfulness. Love in marriage is to be modeled after God's faithful love for his people and Jesus's love for others. Married love is to remain constant in the "joys and sorrows that all the years may bring." Fidelity includes commitment to the other's good, even amid the changes that each shall undergo. It includes the willingness to forgive and begin anew. It means affirmation and acceptance of the partner as partner, no matter what the judgments of the world are with regard to life in the world. It obviously means fidelity in sexual matters so that the deepest intimacies are never violated by moving them outside the bond. It means the willingness to become dependent on the other-physically, emotionally, and spiritually. It means enduring partnership in bearing and nurturing children and in broader service to the world.

Married life under the bond of agape love is not all heavy and serious. It is within the comfort and security of faithful love that many kinds of spontaneities can flourish. It provides space for fun, for secure delight in all the pleasures of marital life. This transcendent love builds upon earthly loves - erotic, pragmatic, romantic, and friendship - that the Creator has built into creation to draw woman and man together. A number of these mutual loves have to be strongly present in the relationship of married lovers. But such loves, important as they are, are unstable because of human sin and finitude. Partners change with time, they intentionally and unintentionally violate each other and their relationship, and they have rough edges that never are completely ironed out and thereby become sources of discontent.

Agape provides the capacities for steadfastness and reconciliation that can overcome the turbulence caused by the disruption of mutualities that are bound to occur. Agape disposes each partner to repent, initiate forgiveness, and work at building up the bond that simply cannot be free of problems.

${ }^{13}$ Lutheran Book of Worship. 
Agape also lures both partners from focusing on themselves to caring for others, first to the bearing and nurturing of children, if that is their aim, as well as to the service of others in their callings in work, church, society, and world.

\section{Hope}

One salutary dimension of Christian hope is that our salvation is finally not dependent on our performance in marriage. Our acceptance by God is dependent on his free grace in Christ, not our work. This is a source of firm hope for several reasons. First, we are freed from placing ultimate trust in a "successful marriage" or even in our spouse. This gives us needed distance from both so that we will not have the wrong kind of expectations of any human connection. We need not frantically grasp at perfection and thereby fail to receive the blessings that have already been given. Second, we are assured of the daily forgiveness of God that enables us to pick up our lives and live them anew every day, even amid our flawed marriages. That gives us the needed hope to continue. We can move into the future.

Because we know we are offered anew this grace every morning, we can hope for a time of completion. Our marriage vows include the supplication that we might "grow in holy love until life's end."14 Further, they express the hope that "the joy that begins now will be brought to perfection in the life to come," and that we "may at length celebrate with Christ the marriage feast which has no end."'15

There may be no giving and taking in marriage in heaven, but certainly those bonds of faithful love that have been shaped on earth as a sign of the kingdom will not be lost in the fulfillment of that kingdom. As with all approximations of the kingdom, the bonds of marriage will be drawn by the good power of God to himself in his good time. All the fragile, flawed, and interrupted relations of earth will find their permanence and completion in heaven. In this can we hope.

So, we have faith, love, and hope. According to the measure we have been given by the Spirit, marriage becomes transparent to God's presence and will. Shored up and supported by the Christian community, it becomes a calling that is central to the Christian life.

\footnotetext{
${ }^{14}$ Lutheran Book of Worship, 203.

15 Ibid.
} 


\section{Homosexuality}

Before we move to this highly contested issue, it is important to note that our first priority as a church ought to be addressed to concerns directly surrounding heterosexual marriage - the high incidence of divorce, abortion, pre-marital sex and out-of-wedlock births. As I argued above, the church has not yet come to the realization that it has to form its people in a far more disciplined and intentional way. The culture, instead of supporting the church's vision, is now moving in the opposite direction.

Nevertheless, the topic that challenges us right now is that of homosexuality. Issues surrounding homosexuality - the church's blessing of homosexual marriage and the ordination of open homosexuals - have divided all mainstream Protestant communions. These issues - and the acceptance of homosexual conduct that they assume - are so controversial because they seem to impinge upon the moral core of Christianity. Two of the Commandments, for example, assume and are directed toward the heterosexual structure of creation and marriage that I spoke of earlier. These Commandments seem to indicate that departures from that structure are indeed violations of the core. If my prior argument is biblically and theologically cogent, then there can be no "marriage" of homosexuals. The Bible and tradition seem utterly clear that God intends the heterosexual covenant of marriage as the context for sexual relations. One hardly needs specific prohibitive texts against homosexual behavior, though there are many. (No texts, however, even remotely endorse homosexual relations. That is in contrast with those pertaining to slavery and the status of women, about which there are texts that subvert the dominant practices of that time.)

The proponents of homosexual marriage operate out of two faulty propositions. The first is that faithful love is the only relevant moral principle. Faithful love makes a relationship good and moral, and since homosexuals exhibit faithful love in their relations, that is all that matters. The forms or kinds of persons involved in the relation are not morally relevant. The second is that the homosexual orientation, since it is "given," not chosen, is a gift of God, and therefore good. Though it is a minority orientation, it is just different, not defective. Therefore, the expression of sexual love between persons of such orientation is good and appropriate, if governed by the same norms that govern faithful love among heterosexuals.

To these propositions the classic teaching counters: No, one needs more than love. "All you need is love" is an incomplete ethical principle. Sexual love is appropriate to form, to the kind or form of the persons who engage in it. Thus, the Bible and the Christian moral tradition reject bestiality, incest, pederasty, and homosexuality, even if consent to the relation is present. Such relations are intrinsically disordered and imperfect; they are "unnatural," not according to 
some rational law of nature, but according to the Law of God. Love must be appropriate to form.

The same sort of reply is made about the homosexual orientation, whether permanent, involuntary, or not. It is a disordered and imperfect state, and the sexual behavior that flows from it is also disordered and defective. The orientation, if it is permanent, is something of a mini-tragedy. It is not what God intends; it is a symptom of a fallen creation. It impedes the person from pursuing his or her natural sexual telos. It blocks one from "knowing" and coming to terms with the "other" of the opposite sex. It leads to a conflict between one's body and one's orientation. It disallows procreation. It leads to a mismatch between sexual natures if the orientation is acted out. Acted out, the orientation often leads to many diseases and infections, and most likely to a shortened life. This does not mean that the homosexual person as person is disordered, only his or her sexuality. Many homosexual persons are healthier and more productive than I. Neither does it mean that there are no "goods" in faithful and loving homosexual relations. There are. But wholehearted approval of these goods is diminished by the disordered sexuality in which some of them are expressed.

There is little warrant, then, for abandoning the "appropriate to form" requirement for the expression of sexual love, neither among Christians in general nor especially among the leadership of the church. This does not mean, however, that Christians cannot have a nuanced and compassionate approach to these controversial issues. Without relaxing its affirmation of only heterosexual sex within the marriage covenant, the church can strongly insist that the Gospel is addressed to all sinners. Homosexual sex is not some especially heinous sin that cuts one off from God's grace. Consistent with this, inclusion within the church and its pastoral care is obligatory.

\section{A Pastoral Approach}

As with all sin, though, forgiveness follows repentance and leads to efforts to follow God's Commandments. The church should continue to call those are homosexual by orientation - whatever its provenance or duration - to a "heroic" response. That is, they should be called to practice sexual abstinence, sublimating their sexual energies into other pursuits. The church has long honored such "heroic" responses and should continue to do so. It would be naïve to argue that this can be the church's only response for lay Christians. In our present culture, some lay Christians who are homosexual by orientation will engage in sexual relations with members of their own sex. Some will act promiscuously but others will seek more stable unions. Many homosexuals will remain "in the 
closet" and participate incognito in church life, but others will insist that the church formally recognize their sexual identity and bless their unions. Gays and lesbians of all sorts of persuasion are present in our churches, and there seems to be widespread confusion about the church's proper pastoral response to this fact. Given the normative teaching outlined above, what pastoral strategy toward homosexuals should be adopted by churches and Christian individuals?

I would propose a strategy of gracious tolerance. ${ }^{16}$ By "gracious" I mean that the church-both clergy and lay-should greet all persons coming into the fellowship of the church with a warm welcome. After all, we are a company of forgiven sinners. Many homosexuals who prefer to keep their sexual identity private will accept this welcome and participate fully in the life of the church. Those who are in partnered relationships may also wish to keep the sexual nature of their friendships hidden or unclear. As long as such persons do not openly violate or flaunt the normative teachings of the church, they should also be greeted and accepted graciously. The church can even affirm the rich elements of friendship in their ongoing relationship, though not its sexual elements. The latter need not be revealed or probed, and certainly not "blessed." The church does not probe others who do not live up to the moral ideals of the church. Kindliness, inclusion, and support would be the order of the day in these cases, as it is for all the church's members. Repentance, forgiveness, and amendment of life should be left for homosexuals to work out privately, as is the case for other persons who struggle with the demands of the Christian life.

For those who are struggling with sexual identity in their lives, "graciousness" would mean first of all an effort to help them sort out who they are and who they wish to become. Though some homosexuals seem irretrievably caught in their same-sex desires, many young people are simply confused about their sexual identities. It is gracious and helpful to the latter to help them move toward heterosexual desires so that they can grow in that direction in their prospective sexual relationships. For those persons who have inclinations toward same-sex desires but who want to move toward a heterosexual identity, various therapies may be helpful. For both kinds of persons, it is particularly important that the public teaching of the church affirm heterosexual norms.

For those who seem "fixed" in their orientation, it is consistent with our argument above to counsel abstinence. Like other singles, homosexuals are called to refrain from sexual relations. In cases in which abstinence is not being observed, it is gracious privately to encourage sexual fidelity within committed friendships. Such an arrangement is far better than the dangerous promiscuity practiced by a significant portion of the homosexual subculture. From a Christian point of view, it is the lesser of evils. But their sexual relations are still disordered and imperfect, even though other elements in their friendship

${ }^{16}$ A fuller exposition of "gracious toleration" can be found in my Ordinary Saints, 155-158. 
are admirable. It is important continually to hold up the Christian ideal before such homosexual pairs. Perhaps in time they can work toward celibate friendships. Such an approach assumes a strong pastoral love and commitment to such persons. Without that the pastoral counseling will come across simply as judgmental hectoring.

It would be disastrously wrong publicly to bless such arrangements because we simply have no mandate from scripture to bless that which is not blessable. Further, it would send too many wrong messages to the church. To those who regard homosexual relations as sinful, it would signal that the church blesses sin. To those who are struggling with their own sexual identity, it would put an imprimatur on desires and activities they need to resist. Opposition to public blessing reminds us that there are limits to the church's graciousness. Those limits have to do with tolerance, the second word in our phrase, gracious tolerance.

Tolerance does not mean that anything goes, as our permissive culture tends to view it. Tolerance, while it suggests a liberal and open-minded attitude toward persons whose beliefs and actions are different from one's own, also denotes forbearance and endurance. Tolerance, therefore, has its limits. (A bridge, for example, tolerates a certain tonnage but no more.) We tolerate - that is, we forebear and endure- - beliefs and actions that diverge from our own. However, if certain beliefs and actions violate our core convictions, we do not tolerate them. We oppose them and act against them. And properly so; personal integrity and courage are at stake. On the other hand, our level of tolerance is more elastic with regards to beliefs and actions that go counter to our less crucial or central values, such as our preferences, tastes, or opinions.

The church, like individuals, can tolerate all sorts of opinions and practices that involve peripheral matters. It can allow a great deal of latitude on how Christians should apply Christian moral teachings to issues of public policy. It can tolerate a number of forms of worship and preaching. It can tolerate sharp disagreements about practical matters that, while important, are not essential to the core teaching and practices of the church. It can even tolerate many persons whose behavior is out of line with its teaching. Indeed, it can - and must-tolerate all of us sinners who fall short of what the commandments of God demand. In a sense, we are all tolerated by the church.

However, the church is the Body of Christ, responsible for maintaining its apostolic religious and moral teaching. It is entrusted by its Lord with the gospel - the full-blown Trinitarian faith, as well as with the central practices that follow from it. Certainly the commandments are included in its moral core. Therefore, direct, public challenges in word and deed to its core convictions and practices simply cannot be tolerated. Challenges to the tradition's teaching on homosexuality are directed at that core.

This does not mean that those core convictions and practices cannot be discussed and debated. There must be a zone of freedom where persons can carry 
on spirited conversation on central issues that are puzzling or even offensive to them. The youth of the church must be allowed to ask questions about those key issues. At regional and national levels of the church there is room for such discussion. But the proliferation of opinions on these occasions should not confuse or qualify the normative teaching of the church in its preaching or teaching. At the level of normative official teaching and preaching, the church has a tradition to convey clearly and confidently. It has settled teachings. Official representatives of the church are obligated to preserve and convey that tradition until it is officially changed, and on core issues, that change can only come after decades of reflection, discussion, and prayer.

With regard to these sexuality issues, the church cannot tolerate significant "cultures of dissent" that publicly impugn the teaching of the church by contrary teaching and behavior. Permissiveness toward such dissent makes the church appear hypocritical, ineffectual, or unwilling to hold dissenters accountable to its moral teachings. In recent years it has led to crises of sexual misconduct in both Protestantism and Catholicism. Likewise, if it is to be one church, it cannot tolerate public repudiation of its teachings by individual congregations or regional units. The one church must maintain its normative tradition in a disciplined fashion until it is changed.

Finally, the church cannot tolerate relentless and unceasing challenges to its normative teaching on sexuality. Such is the route to depletion and decrease. There has to be an agreement that its settled convictions cannot be challenged indefinitely. Once a church has re-affirmed its teaching, there has to be a decent interval of surcease from continued challenges.

\section{Bibliography}

Bellah, Robert, Richard Madsen, William S. Sullivan, Ann Swidler, and Steven M. Tipton. Habits of the Heart: Individualism and Commitment in American Life. Berkeley, CA: University of California Press, 1985, 1996.

Benne, Robert. Ordinary Saints: An Introduction to the Christian Life. Minneapolis: Fortress Press, 1988, 2003.

Bonhoeffer, Dietrich. Letters and Papers from Prison. London: S.C.M. Press, 1953.

Lutheran Book of Worship. Philadelphia: Board of Publication, Lutheran Church in America, 1978.

Luther, Martin. American Edition of Luther's Works. Edited by Jaroslav Pelikan and Helmut Lehmann. Philadelphia: Fortress Press; St. Louis: Concordia Publishing House, 1955-1986. 
Robert Benne

\title{
Saint Commandement de Dieu
}

\author{
Résumé
}

Dans cet article, on soutient que l'Église doit ériger la théologie du mariage de manière ordonnée, car la culture n'a plus de fondement dans la pensée chrétienne. L'essence de l'argumentation repose sur la distinction provenant de la tradition luthérienne des «deux voies du royaume de Dieu». Selon cette distinction, nous partageons avec d'autres personnes des «lieux de responsabilité», mais avec les vertus chrétiennes de foi, d'espérance et d'amour, nous les transformons en lieux du rayonnement du christianisme. Ensuite, je plaide fermement pour le rejet permanent du mariage homosexuel chez les chrétiens orthodoxes. En conclusion, j'inclus ce que j'espère être une approche pastorale compatissante - une tolérance gracieuse - envers les chrétiens homosexuels.

Mots-clés: individualisme, lieux de responsabilité, foi, amour, espérance, tolérance gracieuse

\section{Robert Benne}

\section{Santo comandamento di Dio}

\section{Sommario}

In questo articolo si sostiene che la Chiesa deve stabilire la teologia del matrimonio in modo ordinato, perché la cultura non ha più un fondamento nel pensiero cristiano. L'essenza dell'argomentazione si basa sulla distinzione che deriva dalla tradizione luterana delle «due vie del regno di Dio», secondo cui condividiamo con altre persone «luoghi di responsabilità», però li trasformiamo in luoghi di radiosa cristianità con le virtù cristiane di fede, speranza e amore. Si sostiene anche il rifiuto permanente del matrimonio omosessuale tra cristiani ortodossi. In conclusione, si include quello che spero sia un approccio pastorale compassionevole - la graziosa tolleranza - verso i cristiani omosessuali.

Parole chiave: individualismo, luoghi di responsabilità, fede, amore, speranza, graziosa tolleranza 